DOI: 10.46340/eppd.2020.7.5.17

\author{
Viktor Leshchynskyi, PhD in Public Administration \\ ORCID ID: https://orcid.org/0000-0002-3916-0146 \\ Kyiv, Ukraine
}

\title{
ADMINISTRATIVE ACT AND MODERN MECHANISMS OF ADMINISTRATIVE AND LEGAL SECURITY AND PROTECTION OF HUMAN RIGHTS AND FREEDOMS: PROBLEMS OF RELATIONSHIP
}

\author{
Віктор Лещинський, к. н. держ. упр. \\ Київ, Україна

\section{АДМІНІСТРАТИВНИЙ АКТ ТА СУЧАСНІ МЕХАНІЗМИ \\ АДМІНІСТРАТИВНО-ПРАВОВОГО ЗАБЕЗПЕЧЕННЯ \\ І ЗАХИСТУ ПРАВ ТА СВОБОД ЛЮДИНИ: ПРОБЛЕМАТИКА СПІВВІДНОШЕННЯ}

\begin{abstract}
The article is devoted to the disclosure of the relationship between the administrative act and modern mechanisms of administrative and legal support and protection of human rights and freedoms, the development of scientifically sound proposals for improving current administrative legislation. It is determined that an administrative act can be considered not only as own decision of the subject of public authority but also - in a broad context: in unity with the procedures for its adoption and implementation. The article states that the mechanisms of administrative and legal support and protection of human rights and freedoms affect the administrative procedures for the adoption and application of an administrative act both at the level of its specific elements and at the level of its principles and basic foundations. For example, the defining objectives of registration administrative procedures are, in particular: formal recognition of a subjective right; certification of status in order to create conditions for further realization of subjective rights, freedoms, legitimate interests. This presupposes the appropriate construction of the outlined procedures. As a result of the study, it was determined that at the level of specific elements, the influence of mechanisms of administrative and legal support of subjective rights, including human rights, is manifested in the signs of registration procedures: a clear sequence of actions of subjects of administrative procedure; specificity and availability of these entities; the significant scope of registration activities, which allows covering the necessary area of subjective rights, freedoms, legitimate interests; the possibility of ap pealing the decision of the subject of the registration procedure.
\end{abstract}

Keywords: administrative act, administrative and legal support, protection of human rights and freedoms, human rights and freedoms, public administration.

Актуальність теми. Стратегією реформування державного управління України до 2021 року, схваленою розпорядженням Кабінету Міністрів України від 24 червня 2016 р. № 474-р ${ }^{1}$ принципи верховенства права визначено основою демократичного врядування. У актуальних наукових публікаціях забезпечення прав і свобод людини визначається основним напрямом подальшого розвитку публічного управління та наголошується на актуальності таких кроків, як: переосмислення ролі позитивістської правової доктрини та послідовне впровадження субстантивної концепції права; актуалізація людиноцентричних підходів у розвитку владних правовідносин на основі визнання людини первинним суб'єктом права та його визначальною

${ }^{1}$ Розпорядження про Деякі питання реформування державного управління Украӥни 2016 (Кабінет Міністрів України). Офіційний вісник Украӥни, 55, 1919. 
цінністю; розвиток інституалізації взаємодії громадськості та влади у випадку порушення владою прав людини та деякі інші ${ }^{1}$.

Аналізуючи актуальні проблеми сучасної системи державного управління у сфері містобудування, необхідно вказати не тільки про певні недоліки інституційного, але й істотні проблеми правозастосовного характеру. Так, прикладом перших можна навести випадки невідповідності юрисдикції суб'єктів владних повноважень їх правовій природі ${ }^{2}$, прикладом других поширеність корупції ${ }^{3}$, суб'єктивізму ${ }^{4}$ у вказаній сфері проявів. Представники як академічної спільноти, так і сфери правозастосування наголошують на необхідності комплексних змін у системі державного управління містобудуванням ${ }^{5}$.

Впливовим системоутворюючим чинником наведених недоліків вбачається саме недостатня реалізація людиноорієнтовного підходу удержавному управлінні, в тому числі і усфері містобудування. У цьому контексті особливу актуальність представляють перспективи прийняття та застосування адміністративного акту як найчастіше застосованого інструмента у державному управлінні ${ }^{6}$. Поширеність застосування адміністративного акту як інструмента державного управління відповідає його такій ролі у європейському просторі ${ }^{7}$.

Огляд останніх досліджень i публікацій. Проблематиці сутності та застосування адміністративних актів приділено значну увагу у національній доктрині адміністративного права, це $є$ однією з усталених категорій. Необхідно вказати на роботи таких відомих вчених, як В.Б. Аверянов, Д.М. Бахрах, Ю.П. Битяк, Є.Ф. Демський, В.К. Колпаков та багатьох інших. Останні публікації стосуються розвитку окремих видів вказаних актів, зокрема дозволів (О.В. Джафарова, 2015 р. ${ }^{8}$; О.Н. Свтушенко, 2014 р. ${ }^{9}$ ). Адміністративно-правові механізми забезпечення і захисту прав людини як наукова проблематика поступово набувають актуальності у публікаціях окремих науковців (О.В. Легка, 2017 p. ${ }^{10}$; Р. Зуєв, 2011 p. ${ }^{11}$; О.О. Небрат та В.П. Яценко, 2017 p. ${ }^{12}$ ). Втім, проблематиці місця механізмів адміністративно-правового забезпечення і захисту прав та свобод людини у процедурі прийняття та застосування адміністративного акту належної уваги приділено не було.

Метою статті є розкриття проблематики співвідношення адміністративного акту й сучасних механізмів адміністративно-правового забезпечення і захисту прав та свобод людини, вироблення науково обгрунтованих пропозицій щодо вдосконалення актуального адміністративного законодавства.

Основний матеріал. Адміністративний акт розглядається у юридичній літературі як основний інструмент впливу конкретного характеру, тобто на конкретного суб'єкта адміністративно-правових відносин. Виділяють такі ознаки адміністративного акту: виключно індивідуальна дія (на відміну

\footnotetext{
${ }^{1}$ Петровський, П. (2015). Забезпечення прав і свобод людини - основний тренд модернізації публічного управління. Efficacy public administration, 43, 19.

${ }_{2}^{2}$ Постанова про затвердження Порядку проведення обстеження прийнятих в експлуатацію об'єктів будівництва 2017 (Кабінет Міністрів України). Офіиійний вісник Украӥни, 33, 1045.

${ }^{3}$ Кудрявцев, О. (2019).Дозвільна система має бути єдиною і справедливою до кожного учасника будівельного ринку. Гордон.иа. <https://gordonua.com/ukr/news/money/-dozvilna-sistema-povinna-buti-jedinoji-i-spravedlivojido-kozhnogo-uchasnika-budivelnogo-rinku-kudrjavtsev-1409988.html>. (2020, вересень, 05).

${ }^{4}$ Постанова про часткове задоволення касаційної скарги 2020 (Касаційний адміністративний суд Верховного суду України). <://reyestr.court.gov.ua/Review/89251080>. (2020, вересень, 05).

${ }^{5}$ Стукаленко, О.В. (2017). Адміністративно-правове забезпечення будівельної галузі: монографія. Київ: Центр учбової літератури, 5.

${ }^{6}$ Галунько, В., Діхтієвський, П., Кузьменко, О., Стеценко, С. (2018). Адміністративне право Украӥни. Повний курс: підручник. Херсон: ОЛДІ-ПЛЮС, 158.

${ }^{7}$ Грицяк, І.А. (заг. ред.) (2011). Стандарти європейського врядування: навчальний посібник. Київ: НАДУ, 19, 24. ${ }^{8}$ Джафарова, О.В. (2015). Дозвільна діяльність органів публічної адміністрації в Україні: адміністративноправові засади: автореферат дисертації докторра юридичних наук. Харків.

${ }^{9}$ Свтушенко, О.Н. (2014). Управлінські рішення: сутність та характерні риси. Наукові праці Чорноморського державного університету імені Петра Могили комплексу «Києво-Могилянська академія». Серія: Державне управління, 239, 237, 47-51.

10 Легка, О.В. (2017). Поняття та значення міжнародних стандартів для адміністративного законодавства України. Міжнародний науковий журнал «Верховенство права», 5, 60-65.

11 Зуєв, Р. (2011). Щодо механізму адміністративно-правового забезпечення прав людини. Юридична Україна, $8,46-51$.

12 Небрат, О.О., Яценко, В.П. (2017). Адміністративно-правовий механізм забезпечення прав і свобод людини в діяльності Національної поліції. Міжнародний науковий журнал «Верховенство права», 5, 93-99.
} 
від нормативного); ухвалюється у визначеному законом порядку; спрямований на настання наслідків юридичного характеру - прав та обов'язків ${ }^{1}$. Відмічаючи грунтовність зазначених наукових напрацювань, зауважимо про їх описовий характер, оскільки вони відображають передусім зовнішні ознаки адміністративного акту, не заглиблюючись у його сутність. Тому проведення цього дослідження передбачає врахування відповідних наукових напрацювань.

О.Н. Євтушенко, характеризуючи сутність управлінського рішення, вказує на єдність власне рішення із зокрема: його причинами; організацією його прийняття. Істотне значення надається також контролю за виконанням рішення, впливу його на зовнішні обставини ${ }^{2}$. Отже, адміністративний акт може розглядатись не тільки як власне рішення суб'єкта публічної влади, але й- у широкому контексті: у єдності із процедурами його прийняття та реалізації.

Людиноцентристська спрямованість сучасного адміністративного права зумовлює опрацювання поняття людини у контексті адміністративного права. Сьогодні у межах цієї галузі права набуває використання категорія «приватна особа», що відображає приватний інтерес як основу участі такої особи у адміністративних правовідносинах. Структура зазначеної категорії $є$ достатньо складною оскільки цілісне поняття приватної особи розглядається у контексті: а) сфери правового регулювання адміністративного права; б) конкретних адміністративно-правових статусів. Так, у першому контексті виділяються: адміністративно-правові відносини (приватна особа є суб'єктом); публічне управління (приватна особа є об'єктом); адміністративно-деліктні правовідносини (приватна особа $є$ суб'єктом) $)^{3}$. Врахування вказаних положень дозволяє окреслити межі та роль засобів адміністративного права у забезпеченні та реалізації прав та свобод людини у публічноправових відносинах.

Щодо поняття механізмів адміністративно-правового забезпечення і захисту прав та свобод людини сьогодні немає єдиної позиції серед представників доктрини адміністративного права. Так, О.О. Небрат та В.П. Яценко, досліджуючи питання таких механізмів у діяльності органів національної поліції опрацьовують проблематику: форм обмежень прав і свобод людини у діяльності національної поліції; розкривають поняття такого механізму та його елементів стосовно діяльності вказаних суб'єктів ${ }^{4}$. Р. Зуєв, досліджуючи загальні питання механізму адміністративно-правового забезпечення прав і свобод людини, вказує про такі його характерні риси, як: вплив на суспільні відносини через норми адміністративного права; реалізується специфічними суб'єктами - органами публічної влади; $\epsilon$ системою взаємопов'язаних елементів; тісний зв'язок із системою соціальних відносин, без якого такий механізм не може функціонувати 5 . О.В. Муза виділяє наступні риси адміністративно-правового механізму захисту суб'єктивних прав, свобод, законних інтересів: притаманність не тільки охоронної функції, але й - регулятивної та захисної; невід'ємною складовою такого механізму виступають процесуальні норми, за допомогою яких реалізуються визначені законом адміністративно-правові засоби; міжгалузевий характер такого механізму, оскільки він не тільки існує у межах адміністративного права, але й визначає конституційні вимоги до забезпечення суб'єктами публічної влади суб'єктивних прав, свобод, законних інтересів ${ }^{6}$. Коментуючи вказані позиції, можна вказати як на їх певні риси, що заслуговують на окрему увагу, так і певні спірні положення. У позитивний бік необхідно відмітити інституційний контекст формування самої категорії «адміністративно-правовий механізм забезпечення суб'єктивних прав, свобод, законних інтересів». Це є актуальним з огляду на визнання національною правовою системою європейських правових цінностей та правових

\footnotetext{
${ }^{1}$ Галунько, В., Діхтієвський, П., Кузьменко, О., Стеценко, С. (2018). Адміністративне право Украӥни. Повний курс: підручник. Херсон: ОЛДІ-ПЛЮС, 158; Александрова, Н. (2003). Класифікачія правових актів управління. Державне управління адміністративно-правової теорії та практики. Київ: Факт, 151; Тимощук, В. (2010). Адміністративні акти: процедура прийняття та припинення дії: монографія. Київ: Конус-Ю, 25. ${ }^{2}$ Євтушенко, О.Н. (2014). Управлінські рішення: сутність та характерні риси. Наукові праці Чорноморського державного університету імені Петра Могили комплексу «Києво-Могилянська академія». Серія: Держсавне управління, 239, 237, 49.

${ }^{3}$ Галунько, В., Діхтієвський, П., Кузьменко, О., Стеценко, С. (2018). Адміністративне право України. Повний курс: підручник. Херсон: ОЛДІ-ПЛЮС, 109-110.

${ }^{4}$ Небрат, О.О., Яценко, В.П. (2017). Адміністративно-правовий механізм забезпечення прав і свобод людини в діяльності національної поліції. Міжнародний науковий журнал «Верховенство права», 5, 96-98.

5 Зуєв, Р. (2011). Щодо механізму адміністративно-правового забезпечення прав людини. Юридична Украйна, 8,50 .

${ }^{6}$ Муза, О.В. (2014). Адміністративно-правовий механізм захисту прав, свобод та інтересів фізичних і юридичних осіб в Україні. Наукові записки Інституту законодавства Верховної Ради Украӥни, 6, 35.
} 
підходів та може бути взяте за основу для подальшого дослідження. 3 іншого боку, не отримала належної уваги актуальна проблематика адміністративно-правового забезпечення саме тієї частини суб'єктивних прав, свобод, законних інтересів, що складає права та свободи людини.

У контексті реалізації прав та свобод людини має теоретичне та практичне значення класифікація адміністративних актів за критеріями: характеру дії; отримуваного внаслідок застосування конкретного акту результату. За першим критерієм виділяються: обтяжувальні (невигідні для реалізації прав та свобод особи, наприклад відмова у видачі дозволу); сприяльні (сприяють реалізації суб'єктивних прав, свобод, законних інтересів, наприклад видача дозволу). Окремо виділяються змішані (мають одночасно частково сприяльну та частково обтяжувальну дію для однієї й тієї ж особи) та акти подвійної дії (можуть стосуватись третіх осіб). За другим критерієм виділяються: підтверджувальні (засвідчення статусу), обтяжувальні (зменшення розміру соціальних виплат); сприяльні (підтвердження наявності певного права) ${ }^{1}$. Отже, з наведених положень слідує висновок про безпосередній вплив адміністративних актів управлінського характеру на реалізацію прав та свобод людини: на підприємницьку діяльність (ст. 42 Конституції України від 28.06.1996 р. № 254к/96-ВР (далі - Конституція України) $)^{2}$ ); втручання в особисте i сімейне життя (ст. 32 Конституції України); володіння, користування та розпорядження своєю власністю (ст. 41 Конституції України) та інших.

Реалізації адміністративного акту передує його прийняття, що має відбуватись із суворим дотриманням вимог законодавства, оскільки прийняття адміністративного акту $є$ елементом правозастосовного процесу. Такими $є$ вимоги щодо адміністративних процедур прийняття адміністративного акту. Актуальні наукові напрацювання свідчать про виділення трьох основних видів процедур у адміністративному процесі: адміністративно-судовий процес; адміністративноуправлінський процес; адміністративно-юрисдикційний процес. Адміністративні процедури притаманні саме адміністративно-управлінському процесу. Ознаками адміністративної процедури виступають зокрема, такі: грунтуються на положеннях чинного законодавства; спрямованість на реалізацію та захист суб'єктивних прав, свобод, законних інтересів ${ }^{3}$. Отже, механізми адміністративно-правового забезпечення i захисту прав та свобод людини впливають на адміністративні процедури прийняття адміністративного акту як на рівні конкретних іiї елементів, так і на рівні їі принципів.

Наведена теза підтверджується за результатами опрацювання конкретних видів адміністративних процедур. Зокрема, за критерієм сутності процедури виділяють такі їх види, як: реєстраційні, дозвільні, процедури за заявою особи та деякі інші. Так, визначальними цілями реєстраційних адміністративних процедур вказують зокрема: офіційне визнання суб' єктивного права; засвідчення статусу. На рівні конкретних елементів вплив механізмів адміністративно-правового забезпечення суб'єктивних прав, в тому числі й прав людини, проявляється у ознаках реєстраційних процедур: чітка послідовність дій суб'єктів здійснення адміністративної процедури; визначеність та доступність вказаних суб'єктів; значна сфера здійснення реєстраційної діяльності, що дозволяє охопити необхідну сферу суб'єктивних прав, свобод, законних інтересів; можливість оскарження рішення суб'єкта здійснення реєстраційної процедури ${ }^{4}$. Як цілі реєстраційної адміністративної процедури, так і її ознаки сприяють створенню умов забезпечення прав та свобод людини.

Іншим прикладом можна навести дозвільні процедури. Зокрема, О.В. Джафарова вказує на спрямованість дозволу як правового засобу на забезпечення реалізації суб'єктивних прав в умовах «людино центристського» характеру сучасної держави України. Визначальною ціллю дозвільної діяльності вказується забезпечення соціальних цінностей, без яких не можуть належною мірою бути реалізовані права та свободи людини: національні інтереси, безпека навколишнього середовища, здоров'я, життя 5 .

\footnotetext{
${ }^{1}$ Галунько, В., Діхтієвський, П., Кузьменко, О., Стеценко, С. (2018). Адміністративне право Украӥни. Повний курс: підручник. Херсон: ОЛДІ-ПЛЮС, 161.

${ }^{2}$ Конституиія України 1996 (Верховна Рада України). Офіційний вісник України, 2010, 72/1, 2598.

${ }^{3}$ Галунько, В., Діхтієвський, П., Кузьменко, О., Стеценко, С. (2018). Адміністративне право Украӥни. Повний курс: підручник. Херсон: ОЛДІ-ПЛЮС, 199-200.

${ }^{4}$ Галунько, В., Діхтієвський, П., Кузьменко, О., Стеценко, С. (2018). Адміністративне право Украӥни. Повний курс: підручник. Херсон: ОЛДІ-ПЛЮС, 202.

5 Джафарова, О.В. (2015). Дозвільна діяльність органів публічної адміністрачії в Україні: адміністративноправові засади: дисертація доктора юрид. наук. Харків, 23, 29.
} 
Вказані положення визначають перспективні напрями подальшого вдосконалення адміністративних процедур прийняття та реалізації адміністративних актів, в тому числі і у сфері містобудування. Одним 3 таких напрямів постає прозорість та передбачуваність адміністративних процедур, що передбачає необхідність вдосконалення законодавчої техніки їх закріплення у нормативних актах. Так, одним з напрямів управління у сфері містобудівної діяльності визначається зокрема надання, відмова унаданні, анулювання (скасування) документів, що дають право на виконання певних робіт або здійснення певних дій (абз. 1 п. 7 ч. 1 ст. 7 Закону України «Про регулювання містобудівної діяльності» від 17.02.2011 p. № 3038-VI). Втім, дії з документами (надання, відмова у наданні, анулювання (скасування) тощо) самі по собі не можуть вважатись актами управління, оскільки таким актом є рішення владного суб'єкта, на виконання якого і мають вчинятись відповідні дії. Тому, з метою врахування сутності управлінської діяльності у сфері містобудування вважаємо за доцільне внести зміни до абз. 1 п. 7 ч. 1 ст. 7 Закону України «Про регулювання містобудівної діяльності» від 17.02.2011 р. № 3038-VI, викласти зазначений абзац в такій редакції: «прийняття рішень реєстраційного, дозвільного та іншого характеру з приводу виконання підготовчих та будівельних робіт, прийняття в експлуатацію закінчених будівництвом об'єктів (крім анулювання (скасування) документів, що засвідчують прийняття в експлуатацію закінчених будівництвом об’єктів) у випадках та порядку, передбаченому законодавством».

Проведене дослідження дозволяє зробити наступні висновки.

Адміністративний акт може розглядатись не тільки як власне рішення суб'єкта публічної влади, але й - у широкому контексті: у єдності із процедурами його прийняття та реалізації.

Механізми адміністративно-правового забезпечення і захисту прав та свобод людини впливають на адміністративні процедури прийняття та застосування адміністративного акту як на рівні конкретних іiї елементів, так і на рівні іï принципів та основних загальних засад. Наприклад, визначальними цілями реєстраційних адміністративних процедур є зокрема: офіційне визнання суб'єктивного права; засвідчення статусу з метою створення умов для подальшої реалізації суб'єктивних прав, свобод, законних інтересів. Це зумовлює відповідну побудову окреслених процедур. На рівні конкретних елементів вплив механізмів адміністративно-правового забезпечення суб'єктивних прав, в тому числі й прав людини, проявляється у ознаках реєстраційних процедур: чітка послідовність дій суб'єктів здійснення адміністративної процедури; визначеність та доступність вказаних суб'єктів; значна сфера здійснення реєстраційної діяльності, що дозволяє охопити необхідну сферу суб'єктивних прав, свобод, законних інтересів; можливість оскарження рішення суб'єкта здійснення реєстраційної процедури.

Вказані положення визначають перспективні напрями подальшого вдосконалення адміністративних процедур прийняття та реалізації адміністративних актів, в тому числі і у сфері містобудування.

3 метою врахування сутності управлінської діяльності усфері містобудування вважаємо за доцільне внести зміни до абз. 1 п. 7 ч. 1 ст. 7 Закону України «Про регулювання містобудівної діяльності» від 17.02.2011 р. № 3038-VI, викласти зазначений абзац в такій редакції: «прийняття рішень реєстраційного, дозвільного та іншого характеру з приводу виконання підготовчих та будівельних робіт, прийняття в експлуатацію закінчених будівництвом об'єктів (крім анулювання (скасування) документів, що засвідчують прийняття в експлуатацію закінчених будівництвом об’єктів) у випадках та порядку, передбаченому законодавством».

\section{References:}

1. Aleksandrova, N. (2003). Klasyfikatsiia pravovykh aktiv upravlinnia. Derzhavne upravlinnia administratyvnopravovoi teorii ta praktyky [Classification of legal acts of management. State Administration of Administrative and Legal Theory and Practice]. Kyiv. [in Ukrainian].

2. Halunko, V., Dikhtiievskyi, P., Kuzmenko, O., Stetsenko, S. (2018). Administratyvne pravo Ukrainy. Povnyi kurs: pidruchnyk [Administrative law of Ukraine. Full course: textbook]. Kherson: OLDI-PLIuS. [in Ukrainian].

3. Hrytsiak, I.A. (ed.) (2011). Standarty yevropeiskoho vriaduvannia: navchalnyi posibnyk [European governance standards: a textbook]. Kyiv: NADU. [in Ukrainian].

4. Dzhafarova, O.V. (2015). Dozvilna diialnist orhaniv publichnoi administratsii v Ukraini: administratyvno-pravovi zasady: avtoreferat dysertatsii doktora yurydychnykh nauk [Permitting activity of public administration bodies in Ukraine: administrative and legal bases: the abstract of the dissertation of the doctor of legal sciences]. Kharkiv. [in Ukrainian]. 
5. Dzhafarova, O.V. (2015). Dozvilna diialnist orhaniv publichnoi administratsii v Ukraini: administratyvno-pravovi zasady: dysertatsiia doktora yurydychnykh nauk [Permitting activity of public administration bodies in Ukraine: administrative and legal bases: the dissertation of the doctor of legal sciences]. Kharkiv. [in Ukrainian].

6. Yevtushenko, O.N. (2014). Upravlinski rishennia: sutnist ta kharakterni rysy [Management decisions: essence and characteristics]. Naukovi pratsi Chornomorskoho derzhavnoho universytetu imeni Petra Mohyly kompleksu «Kyievo-Mohylianska akademiia». Seriia: Derzhavne upravlinnia [Scientific works of the Petro Mohyla Black Sea State University of the Kyiv-Mohyla Academy complex. Series: Public Administration], no. 239, 47-51. [in Ukrainian].

7. Zuiev, R. (2011). Shchodo mekhanizmu administratyvno-pravovoho zabezpechennia prav liudyny [Regarding the mechanism of administrative and legal support of human rights]. Yurydychna Ukraina [Legal Ukraine], no. 8, 46-51. [in Ukrainian].

8. Konstytutsiia Ukrainy 1996 [Constitution of Ukraine 1996] (Verkhovna Rada Ukrainy) [(Verkhovna Rada of Ukraine)]. Ofitsiinyi visnyk Ukrainy [Official Bulletin of Ukraine], 2010, 72/1, 2598. [in Ukrainian].

9. Kudriavtsev, O. (2019).Dozvilna systema maie buty yedynoiu i spravedlyvoiu do kozhnoho uchasnyka budivelnoho rynku [The permitting system must be uniform and fair to each participant in the construction market]. Hordon.ua. <https://gordonua.com/ukr/news/money/-dozvilna-sistema-povinna-buti-jedinoji-ispravedlivoji-do-kozhnogo-uchasnika-budivelnogo-rinku-kudrjavtsev-1409988.html>. (2020, September, 05). [in Ukrainian].

10. Lehka, O.V. (2017). Poniattia ta znachennia mizhnarodnykh standartiv dlia administratyvnoho zakonodavstva Ukrainy [The concept and significance of international standards for the administrative legislation of Ukraine]. Mizhnarodnyi naukovyi zhurnal «Verkhovenstvo prava» [Rule of Law International Scientific Journal], no. 5, 60-65. [in Ukrainian].

11. Muza, O.V. (2014). Administratyvno-pravovyi mekhanizm zakhystu prav, svobod ta interesiv fizychnykh i yurydychnykh osib v Ukraini [Administrative and legal mechanism for protection of rights, freedoms and interests of individuals and legal entities in Ukraine]. Naukovi zapysky Instytutu zakonodavstva Verkhovnoi Rady Ukrainy [Scientific notes of the Institute of Legislation of the Verkhovna Rada of Ukraine], no. 6, 35. [in Ukrainian].

12. Nebrat, O.O., Yatsenko, V.P. (2017). Administratyvno-pravovyi mekhanizm zabezpechennia prav i svobod liudyny v diialnosti Natsionalnoi politsii [Administrative and legal mechanism for ensuring human rights and freedoms in the activities of the National Police]. Mizhnarodnyi naukovyi zhurnal «Verkhovenstvo prava» [Rule of Law International Scientific Journal], no. 5, 93-99. [in Ukrainian].

13. Petrovskyi, P. (2015). Zabezpechennia prav i svobod liudyny - osnovnyi trend modernizatsii publichnoho upravlinnia [Zabezpechennia prav i svobod liudyny - osnovnyi trend modernizatsii publichnoho upravlinnia]. Efficacy public administration, no. 43, 19. [in Ukrainian].

14. Postanova pro zatverdzhennia Poriadku provedennia obstezhennia pryiniatykh v ekspluatatsiiu obiektiv budivnytstva 2017 [Resolution on approval of the Procedure for inspection of commissioned construction projects in 2017] (Kabinet Ministriv Ukrainy) [(Cabinet of Ministers of Ukraine)]. Ofitsiinyi visnyk Ukrainy [Official Bulletin of Ukraine], 33, 1045. [in Ukrainian].

15. Postanova pro chastkove zadovolennia kasatsiinoi skarhy 2020 [Resolution on partial satisfaction of the cassation appeal 2020] (Kasatsiinyi administratyvnyi sud Verkhovnoho sudu Ukrainy) [(Administrative Court of Cassation of the Supreme Court of Ukraine)]. <://reyestr.court.gov.ua/Review/89251080>. (2020, September, 05). [in Ukrainian].

16. Rozporiadzhennia pro Deiaki pytannia reformuvannia derzhavnoho upravlinnia Ukrainy 2016 [Order on Some Issues of Public Administration Reform in Ukraine 2016] (Kabinet Ministriv Ukrainy) [(Cabinet of Ministers of Ukraine)]. Ofitsiinyi visnyk Ukrainy [Official Bulletin of Ukraine], 55, 1919. [in Ukrainian].

17. Stukalenko, O.V. (2017). Administratyvno-pravove zabezpechennia budivelnoi haluzi: monohrafiia [Administrative and legal support of the construction industry: a monograph]. Kyiv: Tsentr uchbovoi literatury. [in Ukrainian].

18.Tymoshchuk, V. (2010). Administratyvni akty: protsedura pryiniattia ta prypynennia dii: monohrafiia [Administrative acts: procedure for adoption and termination: monograph]. Kyiv: Konus-Yu. [in Ukrainian]. 